From the foregoing it would appear that Trachypetus is a very generalized Braconid, perhaps best placed in the subfamily Helconinæ as at present understood unless it be separated as Schulz has done as a monotypical subfamily known only by one species in one sex, a position of very doubtful stability. As I believe that the present unsatisfactory classification of the Braconidæ as a whole can be improved only by a careful examination of the quite considerable number of apparently aberrant forms, $I$ have taken this occasion to discuss and figure Trachypetus.

\title{
AN INFESTATION OF THE WHITE-PINE APHID.
}

By H. B. Peirson, Bussey Institution, Harvard University.

While working at the Harvard Forest, Petersham, Mass., my attention was called to a somewhat isolated clump of white-pine trees, forty to fifty years old, which were dying The trees averaged about fourteen inches D. B. H. and were approximately twelve in number. On two sides of the clump of mature trees were young white-pine plantations. A careful examination showed that the trees were being killed due to an extremely heavy infestation of black aphids which upon identification proved to be Lachnus strobi Fitch., the White-pine Aphid. Many of the larger limbs were barren of foliage, whereas on others the foliage was brown, the individual needles each showing many puncture marks where the aphids had been feeding.

The trees were first examined October 10, 1919, at which time the aphids were laying their eggs on the needles. These are laid end to end generally in lines of five or six, although as many as twenty-seven were found on a single needle, and it was not at all uncommon to find as many as ten or fifteen attached end to end. The eggs were invariably laid on the green needles, and the aphids apparently anticipating the death of the older trees were laying the majority of the eggs on the younger trees in one of the adjacent plantations. Practically all of the needles on the more heavily infested trees had batches of eggs on them.

Large numbers of the aphids were still feeding. These had congregated on the needles and small twigs. The survival of the 
aphids in spite of heavy rains and low temperatures was remarkable, subsequent examinations showed them feeding up until about the first of November. Very few winged individuals were found. The oviparous females are brownish black in color, with a white line along the middle of the thorax. The antennæ are pale, with black tips.

The eggs are smooth and elongate, averaging $.12 \mathrm{~mm}$. in length by $.02 \mathrm{~mm}$. in breadth. They are of a pale yellow tinge when first laid, but in a few hours the color changes to a dark orange, and later to a shiny jet black.

\section{TWO NEW SCHENDYLOID CHILOPODS FROM GUATEMALA.}

By Ralph V. Chamberlin,

Museum of Comparative Zoölogy, Cambridge, Mass.

The interesting new chilopods described below are represented by single specimens taken from soil about the roots of the pacaya or salad palm (Chamædorea sp.) from Coban, Guatemala, at quarantine in Washington, D. C., January 29, 1920, by Messrs. W. B. Wood and H. L. Sanford and transmitted to me for identification from the United States Bureau of Entomology. In addition to the two chilopods, two diplopods were also found, these being Orthomorpha coarctata (Saussure) and Cleidogona sp., the latter being represented by an immature specimen which is possibly C. stolli Pocock.

\section{Sogolabis gen. nov.}

Labrum not free, forming an arc armed with an even series of teeth much as in, e. g., Adenoschendyla.

Claw of palpi of second maxillæ long, the margins smooth, neither pectinate or spined. Pleurosternal suture of second maxillæ complete, sharply marked, the pleurite extending forward to coxosternum.

No ventral pores present.

Coxopleural pores of pregenital segment small, simple, several on each side as in Escaryus.

Anal legs composed of six articles beyond coxopleura, without claw. 

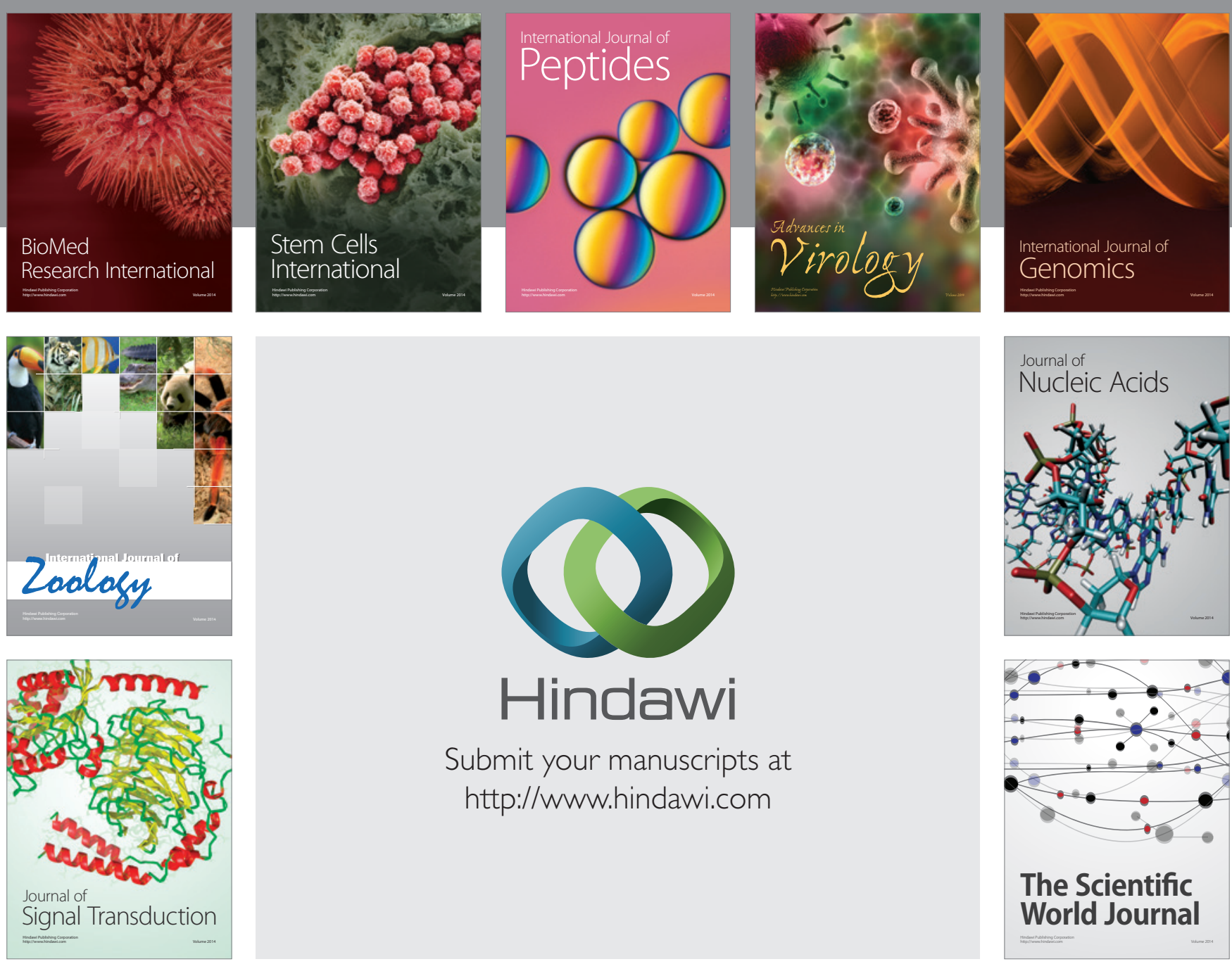

Submit your manuscripts at

http://www.hindawi.com
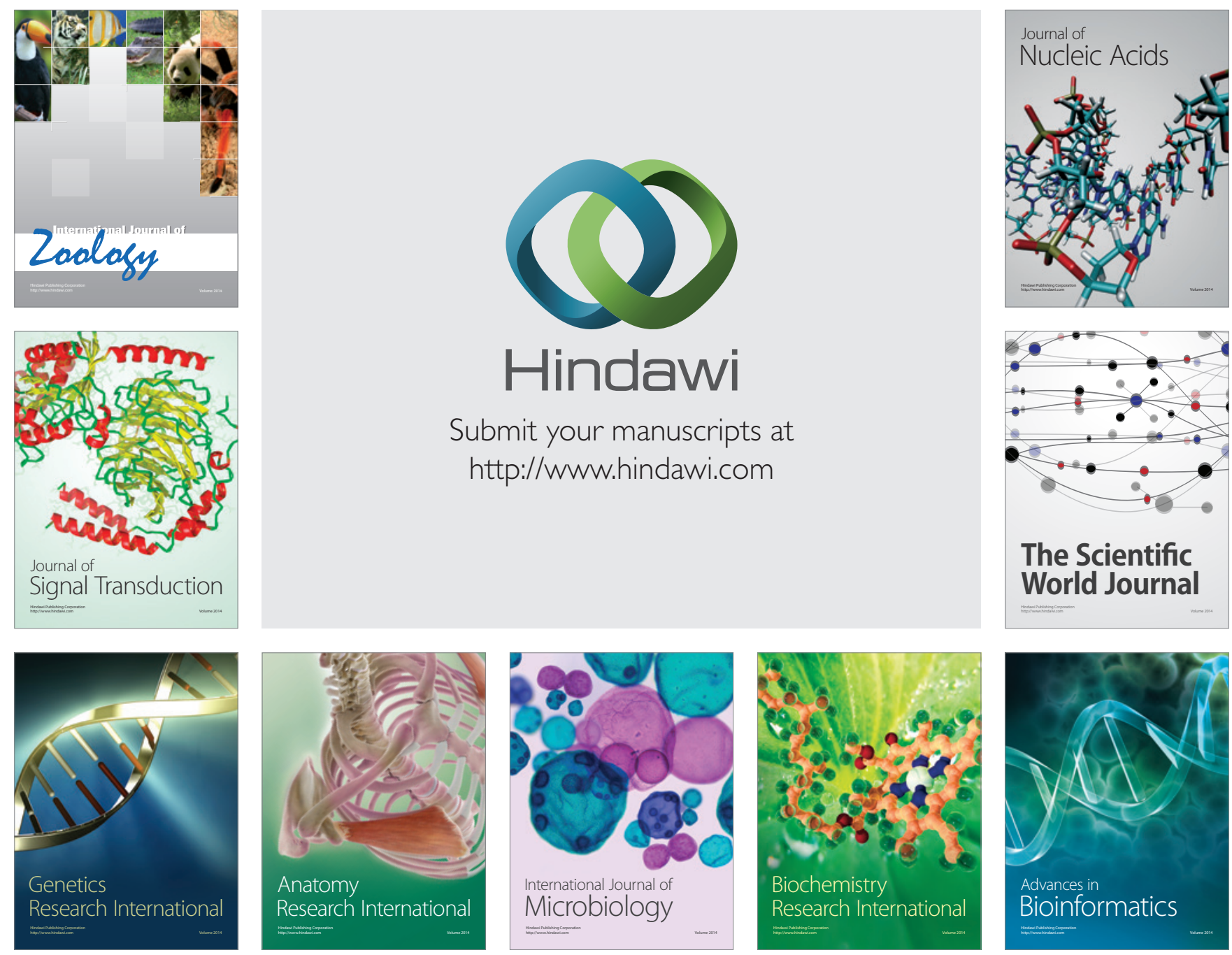

The Scientific World Journal
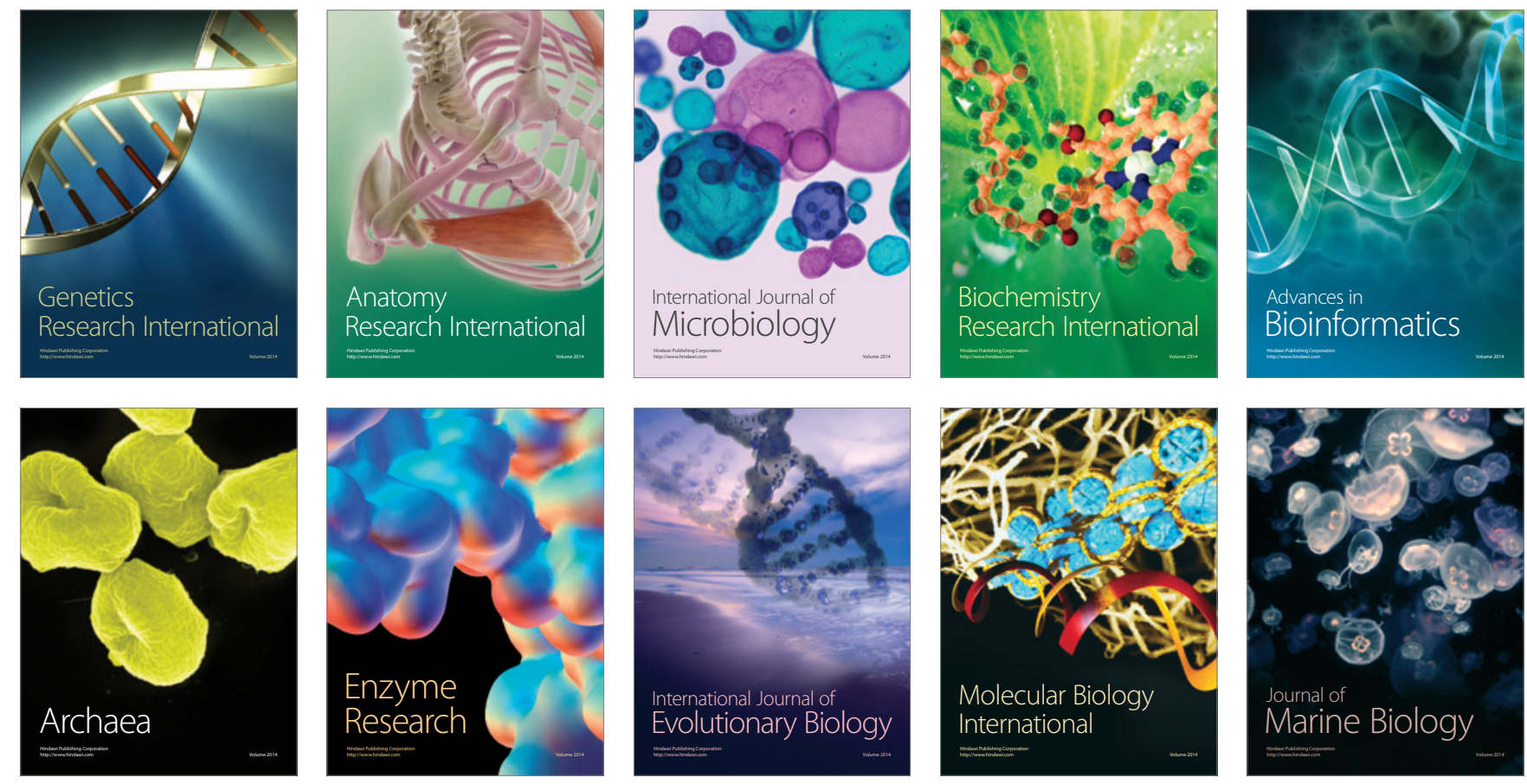